\title{
Guided Cash Payout Policy and Firm Value: Evidence from China
}

\author{
Yin-Che Weng ${ }^{1}$, Shiyu Liu ${ }^{1,2,}$, Yu Qi ${ }^{3}$, Yadi Qin ${ }^{4}$ \\ ${ }^{1}$ Department of Accounting, Harbin Institute of Technology, Harbin, P. R. China \\ ${ }^{2}$ School of Business, Trinity College Dublin, Dublin, Ireland \\ ${ }^{3}$ Department of Finance, University of Texas at Dallas, Richardson, USA \\ ${ }^{4}$ Department of Finance, Xiamen University, Xiamen, P. R. China
}

Email address:

ycw@hit.edu.cn (Yin-Che Weng), samliu@hit.edu.cn (Shiyu Liu), qiyuhit@126.com (Yu Qi), qinyadi@126.com (Yadi Qin)

${ }^{*}$ Corresponding author

\section{To cite this article:}

Yin-Che Weng, Shiyu Liu, Yu Qi, Yadi Qin. Guided Cash Payout Policy and Firm Value: Evidence from China. Journal of Finance and Accounting. Vol. 4, No. 5, 2016, pp. 285-292. doi: 10.11648/j.jfa.20160405.15

Received: August 6, 2016; Accepted: August 22, 2016; Published: September 9, 2016

\begin{abstract}
This study considers the "Guidelines for Cash Dividend Distribution of SSE-Listed Companies" (the "Guidelines") issued by the Shanghai Stock Exchange (SSE) in January 2013 as an exogenous shock to corporate payout policy and assesses the effect of cash dividends on stock performance. The authorities believe that urging firms to pay out no less than $30 \%$ of their annual earnings is attractive to outside investors; however, the study results show that, whereas firms raising dividends to meet the level of payouts in the SSE's "Guidelines" may gain superior valuation relative to the counterparts in the short term, this effect does not exist in the middle term. In addition, young, growing companies and startups that follow the policy suffer from downsized financial slack and future corporate investment levels. The results contribute to the literature on corporate payout policy and financial liberalization and indicate policy implications for the government of China and SSE-listed firms.
\end{abstract}

Keywords: Dividend, Payout Policy, Firm Value, China Market, Regulation

\section{Introduction}

Dividend policy is one of the most crucial corporate policies in modern business, and dividends play a primary role in the valuation of equity. Whether dividend policy affects firm value has been a prevalent topic and has been frequently discussed in the Western academy.

Unlike the bottom-up markets of the United States and Europe, the securities markets in China are typically top-down markets. Because markets in China lack a market history and customs as well as strong finance laws and enforcement systems, the authorities in China seek to develop well-functioning markets by directing firms to practice modern business operations and protecting investors from incurring capital loss because of market speculation. In such an institutional context, corporate payout policy may not be fully discretionary to all firms.

To attract both foreign and domestic institutional investors to the stock market and to further develop the market, the Shanghai Stock Exchange (SSE) released the "Guidelines for Cash Dividend Distribution of SSE-Listed Companies" (the "Guidelines") on January 7, 2013. The "Guidelines" urge companies to distribute minimum cash dividends equal to 30\% of net profits in fiscal year 2013 . Firms that do not follow the "Guidelines" must to declare the difference between expected and realized returns of corporate investment projects to shareholders. In addition, firms paying less than $30 \%$ of net profits must state the reasons for the low payout, plans for undistributed earnings, decisions of the board, and opinions on payout policy from independent directors. The SSE also rewards companies by providing the "Green Channel" for refinancing (seasoned equity offerings), mergers and acquisitions, and reorganization for companies distributing cash dividends of more than $50 \%$ of annual net profits and a dividend yield higher than the 1-year deposit rate. The authorities in China also believe that the "Guidelines" will educate investors regarding value investments and guide companies in capital 
allocation.

Reference [1] documented, over the past two decades, a drastic decline in the number of and percentages of payouts from dividend payers in the United States. They attribute the radical change in corporate practice to a change in firm characteristics and the firms' low propensity to pay. Reference [2] reported that the aggregate dividend paid actually increased but was concentrated in a low number of firms. Reference [3] and [4] linked dividends to the catering theory. They believe that firms pay dividends because managers reasonably cater to the shareholders' preference for dividend change in their desire to inflate the stock price. Reference [5], however, indicated catering incentives persist among firms in common law countries only.

The stage of a firm's life cycle is a crucial determinant of dividend payment. Consistent with a life-cycle theory of dividends, reference [6] indicated that the probability of a firm paying dividends increases with the relative amount of earned equity in its capital structure. In China, reference [7] found that the enterprise life cycle has an indirect impact on dividend distribution by influencing an enterprise's profitability at different stages. Reference [8] suggested that the SSE provide more reasonable guidance based on the enterprise life cycle.

According to differential tax rates theory, tax rates on dividend income for individual shareholders are higher than the tax rates on capital gains; this theory is true in China. Reference [9] noted that the current tax policy in China encourages stock trading and punishes payout policies for cash dividends, thus making cash dividends less attractive to investors.

The study examines stock returns during the announcement period of the "Guidelines" and firm financial data associated with reductions in a firm's established dividends. Using the China Stock Market and Accounting Research (CSMAR) and Resset databases, the main databases of Chinese market data, this study examines the relationship between firm value and cash dividends from 2004 to 2013, with a focus on 2013. The results show that firms that changed from paying less than $30 \%$ of net profits in the current accounting year to the suggested $30 \%$ experienced an increase in Tobin's Q in 2013, but that the effect vanishes in less than 1 year. Furthermore, the results of the full sample analysis show that being a payer or even a quality payer, according to the definition established by Chinese authorities, does not benefit firm value.

This study contributes to literature on dividend and firm performance. The results suggest that investors do not believe that cash payouts increased by firms simply to meet the "Guidelines" are sustainable. In addition, the results are consistent with MM irrelevance theory.

\section{Sample and Methodology}

This study's sample consists of the A-share firms traded on the SSE, and the sampling period is from 2004 to 2013. A list of publicly held companies and essential variables, including Tobin's Q and the market-to-book ratio, are collected from the CSMAR database. The other financial data and firm characteristics are from the Resset database. Because the guideline of $30 \%$ net profit payouts covers all industries in China, firms in the finance and utility industries are not excluded. Companies labeled by the stock exchange as financially constrained because of poor operating performance are excluded from the study.

To test the impact of cash-dividend payouts on firm performance, the following model is estimated:

$$
\text { Tobin's } \begin{aligned}
Q_{t} & =\alpha+\beta_{1} \text { CD } \text { Ratio }_{t-1}+\beta_{2} U P_{t-1}+\beta_{3} \text { SIZE }_{t} \\
& +\beta_{4} L E V E R A G E_{t}+\beta_{5} \text { STAGE }_{t}+\beta_{6} A G E_{t} \\
& +\sum_{i} I N D_{i}+\sum_{q} \text { YEAR }_{q}+\epsilon
\end{aligned}
$$

The firm performance is measured using Tobin's Q; the payout ratio, which is defined as the ratio of the annual cash dividend to net profits, is used as the primary independent variable. Two dummies, $U P$ and $D O W N$, are included to represent the changing status of firms that are qualified payers, according to the official Chinese definition. The variable $U P$ is a dummy for companies that change from paying less than $30 \%$ of net profits to paying $30 \%$ or more in the current year, and $D O W N$ is a dummy for firms that change from paying $30 \%$ or more to less than $30 \%$. In practice, listing companies announce the payout policy in May or June, shortly after disclosing their annual financial reports. The first Tobin's $Q$ is calculated using numbers from the midyear report and is used to evaluate firm value in the short term. The Tobin's Q calculated using numbers from the next annual report is used to examine middle-term performance. Referring to reference [10], Huber-White heteroscedasticity-consistent standard errors are used in the subsample regression for 2013, and the clustering effect is fixed according to Rogers' cluster-robust standard errors in the full-sample estimation.

According to reference [5], the ratio of retained earnings to total assets (RE/TA), STAGE, is included as a measure of the stage of a firm's life cycle. A high RE/TA indicates that a company is mature. Other firm characteristics, such as firm size, leverage, age, industry dummies, and year dummies, are controlled for.

\section{Empirical Results}

Table 1. Summary statistics.

\begin{tabular}{lllllll}
\hline Year & Payer & Non-Payer & QP & Firms & Payer \% & QP \% \\
\hline 2004 & 327 & 315 & 225 & 642 & $50.93 \%$ & $35.05 \%$ \\
2005 & 415 & 298 & 278 & 713 & $58.20 \%$ & $38.99 \%$ \\
2006 & 407 & 365 & 283 & 772 & $52.72 \%$ & $36.66 \%$ \\
2007 & 398 & 374 & 255 & 772 & $51.55 \%$ & $33.03 \%$ \\
2008 & 412 & 380 & 197 & 792 & $52.02 \%$ & $24.87 \%$ \\
2009 & 427 & 386 & 207 & 813 & $52.52 \%$ & $25.46 \%$ \\
2010 & 440 & 376 & 194 & 816 & $53.92 \%$ & $23.77 \%$ \\
2011 & 465 & 366 & 169 & 831 & $55.96 \%$ & $20.34 \%$ \\
2012 & 520 & 342 & 207 & 862 & $60.32 \%$ & $24.01 \%$ \\
2013 & 631 & 266 & 362 & 897 & $70.35 \%$ & $40.36 \%$ \\
\hline
\end{tabular}

Notes: Table 1 gives annual numbers of dividend payers, non-payers, and quality payers. Payers pay dividends in year $t$, and non-payers do not pay. QP is the payer who pays out $30 \%$ percent of distributable net profits to shareholders. 
Table 1 shows summary statistics for the study sample. A steadily growing trend of payers is observed between 2004 and 2012, and a substantial increase in 2013 is considered to be the effect of the "Guidelines." The proportion of payers shows a sharp increase from marginally over $60 \%$ in 2012 to more than $70 \%$ in 2013 . However, as the equity market develops, the SSE allows an increasing number of growth companies and startups to be listed on the exchange; thus, the number of nonpayers grows between 2004 and 2012.

Although the propensity of SSE-listed firms to pay continues rising, the trend for quality payers is the reverse. As defined in the SSE's "Guidelines," companies must pay at least $30 \%$ of their net profits in the current fiscal year. The proportion of quality payers remains nearly one-third between 2004 and 2007 but drops to approximately one-fourth because of the global credit and financial crises. During this period, the SSE index and the price-to-earnings ratio of SSE-listed stocks experience relative historical lows. Immediately following the announcement of the "Guidelines" in January 2013, the quality payers increase in either numbers or percentages.

Table 2. Subsample tests on firm performance and dividend payouts.

\begin{tabular}{lllll}
\hline & Short-term & Mid-term & \\
\hline & $(\mathbf{1})$ & $\mathbf{( 2 )}$ & $\mathbf{( 3 )}$ & $\mathbf{( 4 )}$ \\
\hline \multirow{2}{*}{ CD ratio } & Tobin's Q & Tobin's Q & Tobin's Q & Tobin's Q \\
& -0.0011 & -0.0010 & -0.0131 & -0.0133 \\
UP & $(-0.16)$ & $(-0.15)$ & $(-0.13)$ & $(-0.14)$ \\
& $0.130 *$ & 0.125 & 0.0678 & 0.0670 \\
SIZE & $(1.70)$ & $(1.64)$ & $(0.70)$ & $(0.69)$ \\
& $-0.191 * * *$ & $-0.186^{* *}$ & $-0.261 * * *$ & $-0.259 * * *$ \\
LEVERAGE & $(-2.67)$ & $(-2.53)$ & $(-6.98)$ & $(-6.69)$ \\
& $-2.539 * *$ & $-2.550 * *$ & $-2.290^{* * *}$ & $-2.296 * * *$ \\
STAGE & $(-2.47)$ & $(-2.46)$ & $(-5.62)$ & $(-5.61)$ \\
& $-2.667 * * *$ & $-2.669 * * *$ & $-2.575 * * *$ & $-2.575 * * *$ \\
AGE & $(-29.97)$ & $(-29.67)$ & $(-7.23)$ & $(-7.22)$ \\
& & 0.00602 & & 0.00000626 \\
IND & & $(0.71)$ & & $(0.30)$ \\
Cons & YES & YES & YES & YES \\
& $6.883 * * *$ & $6.669 * * *$ & $8.616 * * *$ & $8.531 * * *$ \\
$N$ & $(5.55)$ & $(4.96)$ & $(10.21)$ & $(9.20)$ \\
$R^{2}$ & 903 & 903 & 533 & 533 \\
\hline
\end{tabular}

Notes: This table presents the regression results of dividend payouts on Tobin's Q in a subsample of 2013. Tobin's Q, the dependent variable, is the market value divided by replacement costs. CD ratio denotes the cash dividend payout ratio. UP is a dummy for companies from paying below $30 \%$ of net profits to paying 30\% and beyond in current year. SIZE is the natural logarithm of total asset, LEVERAGE is the total liability divided by total asset, STAGE is the retained earnings divided by total asset, and AGE denotes the total operating days of the firm since established. IND is the industry dummies. T-statistics are in parentheses.

$* * *, * *$ and $*$ denote Significance at 1,5 and $10 \%$ levels, respectively.

Table 2 shows the regression estimates for the subsample from 2013. The strongest effect of the cash payout on firm value is expected to transpire shortly after the announcement of the "Guidelines." The short-term effect of cash dividends on firm valuation is shown in Columns (1) and (2). Here, the dummy $D O W N$ is not included because no quality payers choose to lower their payout ratios after the introduction of the "Guidelines." The coefficients of cash dividends are negative but insignificant. $U P$, the dummy for firms transforming from low dividend payers to quality payers, is positive with marginal statistical significance. The coefficients of $U P$ are 0.13 and 0.125 in Columns (1) and (2), respectively. In this subsample, no firms "downgrade" themselves from a $30 \%$ payer to a payer of less than $30 \%$. The results suggest that paying dividends does not benefit firm value; however, following the Chinese authorities' policy marginally increases a firm's market value. The models control for the industry fixed effect. Unreported results show that firms in the information, finance, and education industries are associated with high Tobin's Qs.

Columns (3) and (4) show the results of the middle-term evaluation. Because of the length of time and late disclosure of the annual reports, some explanatory power and observations are lost in the middle-term model. An analysis of middle-term performance shows that the dividend payout level remains insignificantly negative and that the $U P$ value is positive but insignificant. Specifically, the significance of upgrading to a quality payer diminishes over time. Small, growing, and low-leverage firms enjoy a high valuation, as measured using Tobin's Q, in China.

Table 3. Full sample tests on firm performance and dividend payouts.

\begin{tabular}{lllll}
\hline & Short-term & \multicolumn{3}{l}{ Mid-term } \\
\hline & $(\mathbf{1})$ & $\mathbf{( 2 )}$ & $\mathbf{( 3 )}$ & $\mathbf{( 4 )}$ \\
\hline & Tobin's Q & Tobin's Q & Tobin's Q & Tobin's Q \\
\hline CD ratio & $-0.0890^{* *}$ & $-0.0840^{* *}$ & $-0.0581^{*}$ & $-0.0575^{*}$ \\
& $(-2.07)$ & $(-2.06)$ & $(-1.71)$ & $(-1.71)$ \\
UP & 0.0643 & 0.0695 & 0.0376 & 0.0382 \\
& $(0.90)$ & $(0.95)$ & $(0.66)$ & $(0.67)$ \\
DOWN & 0.0117 & 0.0348 & -0.0372 & -0.0349 \\
& $(0.22)$ & $(0.59)$ & $(-0.85)$ & $(-0.81)$ \\
SIZE & 0.239 & 0.253 & -0.0830 & -0.0814 \\
& $(1.23)$ & $(1.25)$ & $(-0.96)$ & $(-0.93)$ \\
LEVERAGE & $-6.677 * * *$ & $-6.681 * * *$ & $-4.748 * * *$ & $-4.749 * * *$ \\
& $(-9.91)$ & $(-9.95)$ & $(-3.12)$ & $(-3.12)$ \\
STAGE & $-4.339 * * *$ & $-4.339 * * *$ & $-3.751 * * *$ & $-3.751 * * *$ \\
& $(-27.61)$ & $(-27.64)$ & $(-6.73)$ & $(-6.73)$ \\
AGE & & 0.0000992 & & 0.0000106 \\
& & $(1.38)$ & & $(0.43)$ \\
IND & YES & YES & YES & YES \\
YEAR & YES & YES & YES & YES \\
Cons & -0.256 & -1.036 & $5.245^{* * *}$ & $5.159 * * *$ \\
& $(-0.06)$ & $(-0.22)$ & $(4.29)$ & $(4.13)$ \\
$N$ & 7894 & 7894 & 7532 & 7532 \\
$R^{2}$ & 0.980 & 0.980 & 0.885 & 0.885 \\
\hline \multirow{4}{*}{ L } & & & & \\
\hline
\end{tabular}

Notes: This table presents the regression results of dividend payouts on Tobin's Q in full sample. Tobin's Q, the dependent variable, is the market value divided by replacement costs. $\mathrm{CD}$ ratio denotes the cash dividend payout ratio. UP is a dummy for companies from paying below $30 \%$ of net profits to paying $30 \%$ and beyond in current year, and DOWN is a dummy for firms from paying $30 \%$ or more to less than $30 \%$. SIZE is the natural logarithm of total asset, LEVERAGE is the total liability divided by total asset, STAGE is the retained earnings divided by total asset, and AGE denotes the total operating days of the firm since established. IND is the industry dummies, and YEAR represents the year dummies. We use the Rogers sandwich cluster-robust standard errors in the full sample calculation of t-value. T-statistics are in parentheses.

$* * *, * *$ and $*$ denote Significance at 1,5 and $10 \%$ levels, respectively.

Subsequently, a full sample regression is conducted. The 
overall sample sizes are 7,894 firms for the short-term analysis and 7,532 for the middle-term analysis. The model-fitted R-squared values reach $98 \%$ and $79 \%$ for the short-term and middle-term analyses, respectively. In the short-term analysis, as shown in Columns (1) and (2) of Table 3, a significantly negative coefficient of $C D$ Ratio is observed, whereas UP remains positive even though its statistical significance disappears. In other words, those investing on the SSE do not prefer, in the long term, cash dividends to future growth. Most investors seek capital gains over dividend yields in China, with such a phenomenon being attributed to the personal income tax, low-payout market, and insufficient financial literacy. In China, the capital gains are tax free but the dividends are taxed according to the investor's personal income tax bracket. In a relatively low dividend market, investors have few choices of dividend payers apart from speculating or searching for undervalued companies. In addition, having quality payers that pay no less than $30 \%$ of net profits may be a short-term, policy-oriented effect.

Table 4. Subsample tests on market-to-book ratio and payouts.

\begin{tabular}{lllll}
\hline & Short-term & & Mid-term & \\
\hline & $\mathbf{( 1 )}$ & $\mathbf{( 2 )}$ & $\mathbf{( 3 )}$ & $\mathbf{( 4 )}$ \\
\hline & $\mathbf{M B}$ & $\mathbf{M B}$ & $\mathbf{M B}$ & $\mathbf{M B}$ \\
\hline CD ratio & -0.00309 & -0.00290 & 0.0227 & 0.0218 \\
& $(-0.54)$ & $(-0.51)$ & $(0.24)$ & $(0.23)$ \\
UP & $0.203 * * *$ & $0.194 * * *$ & 0.0913 & 0.0872 \\
& $(2.95)$ & $(2.82)$ & $(1.01)$ & $(0.97)$ \\
SIZE & $-0.122^{*}$ & -0.113 & $-0.207 * * *$ & $-0.198 * * *$ \\
& $(-1.78)$ & $(-1.60)$ & $(-6.58)$ & $(-6.21)$ \\
LEVERAGE & $-2.384 * *$ & $-2.405 * *$ & $-1.865 * * *$ & $-1.894 * * *$ \\
& $(-2.37)$ & $(-2.38)$ & $(-4.95)$ & $(-5.04)$ \\
STAGE & $-2.633 * * *$ & $-2.637 * * *$ & $-2.363 * * *$ & $-2.364 * * *$ \\
& $(-35.80)$ & $(-35.51)$ & $(-7.77)$ & $(-7.76)$ \\
AGE & & 0.0119 & & 0.0000301 \\
& & $(1.46)$ & & $(1.61)$ \\
IND & YES & YES & YES & YES \\
Cons & $5.128 * * *$ & $4.706 * * *$ & $7.050 * * *$ & $6.661 * * *$ \\
& $(4.36)$ & $(3.68)$ & $(9.64)$ & $(8.54)$ \\
$N$ & 903 & 903 & 533 & 533 \\
$R^{2}$ & 0.903 & 0.903 & 0.637 & 0.638 \\
\hline
\end{tabular}

Notes: This table presents the regression results of dividend payouts on market-to-book ratio in a subsample of 2013. Market-to-book ratio, the dependent variable, is the market value divided by the book value of the firm. CD ratio denotes the cash dividend payout ratio. UP is a dummy for companies from paying below $30 \%$ of net profits to paying $30 \%$ and beyond in current year. SIZE is the natural logarithm of total asset, LEVERAGE is the total liability divided by total asset, STAGE is the retained earnings divided by total asset, and AGE denotes the total operating days of the firm since established. IND is the industry dummies. We use Huber-White Heteroscedasticity-consistent standard errors in the calculation of t-value. T-statistics are in parentheses.

$* * *, * *$ and $*$ denote Significance at 1,5 and $10 \%$ levels, respectively.

In the middle-term evaluation, the negative effect of considerable decreases in cash-dividend levels are documented but with marginal significance. Although lacking statistical significance, the $U P$ value is positive and the $D O W N$ is negative in the middle-term evaluation. Generally, the evidence suggests that investors on the SSE focus more on factors other than the dividend level and whether a firm is an officially defined quality payer. Similar results are found in the full-sample analysis for the controlling variables, except for the size effect.

In the robustness check, the Tobin's Q is replaced with the market-to-book ratio. The regression results are shown in Table 4. Columns (1) and (2) show the coefficients of short-term performance. Compared with the results shown in Table 2, the coefficients of cash dividend remain insignificantly negative, but the coefficients of UP become positive with a statistical significance of $99 \%$. The results suggest that markets pay more for firms upgrading to officially defined quality payers, even though the payout level is not significantly associated with firm value in 2013 .

Columns (3) and (4) of Table 4 show the results for the middle-term evaluation. Both the dividend payout level and $U P$ are insignificantly positive. The decrease in statistical significance of $U P$ suggests that the upgrading effect on firm value is extremely time dependent. The coefficients of the controls are comparable to models with Tobin's Q as the dependent variable.

Table 5. Full sample tests on market-to-book ratio and payouts.

\begin{tabular}{|c|c|c|c|c|}
\hline & \multicolumn{2}{|c|}{ Short-term } & \multicolumn{2}{|l|}{ Mid-term } \\
\hline & (1) & (2) & (3) & (4) \\
\hline & MB & MB & MB & MB \\
\hline $\mathrm{CD}$ ratio & $\begin{array}{l}-0.109 * * \\
(-2.13)\end{array}$ & $\begin{array}{l}-0.1000 * * \\
(-2.14)\end{array}$ & $\begin{array}{l}0.0595 \\
(1.10)\end{array}$ & $\begin{array}{l}0.0579 \\
(1.09)\end{array}$ \\
\hline UP & $\begin{array}{l}0.133 \\
(1.54)\end{array}$ & $\begin{array}{l}0.142 \\
(1.61)\end{array}$ & $\begin{array}{l}0.126^{*} \\
(1.90)\end{array}$ & $\begin{array}{l}0.124^{*} \\
(1.89)\end{array}$ \\
\hline DOWN & $\begin{array}{l}0.003 \\
(0.03)\end{array}$ & $\begin{array}{l}0.043 \\
(0.43)\end{array}$ & $\begin{array}{l}0.0943 \\
(1.61)\end{array}$ & $\begin{array}{l}0.0883 \\
(1.56)\end{array}$ \\
\hline SIZE & $\begin{array}{l}1.114^{*} \\
(1.88)\end{array}$ & $\begin{array}{l}1.139 * \\
(1.89)\end{array}$ & $\begin{array}{l}-0.239 * * * \\
(-3.03)\end{array}$ & $\begin{array}{l}-0.243^{* * * *} \\
(-3.14)\end{array}$ \\
\hline LEVERAGE & $\begin{array}{l}-5.783^{* * *} \\
(-3.91)\end{array}$ & $\begin{array}{l}-5.790 * * * \\
(-3.92)\end{array}$ & $\begin{array}{l}2.150 * * \\
(2.21)\end{array}$ & $\begin{array}{l}2.152^{* * *} \\
(2.21)\end{array}$ \\
\hline STAGE & $-4.067 * * *$ & $-4.068 * * *$ & $-1.041 * * *$ & $-1.041 * * *$ \\
\hline AGE & $(-9.16)$ & $\begin{array}{l}(-9.16) \\
0.000171 * \\
(1.74)\end{array}$ & $(-5.05)$ & $\begin{array}{l}(-5.05) \\
-0.0000274 \\
(-1.06)\end{array}$ \\
\hline IND & YES & YES & YES & YES \\
\hline YEAR & YES & YES & YES & YES \\
\hline Cons & $\begin{array}{l}-19.66 \\
(-1.52)\end{array}$ & $\begin{array}{l}-21.01 \\
(-1.56)\end{array}$ & $\begin{array}{l}5.081 \text { *** } \\
(2.80)\end{array}$ & $\begin{array}{l}5.302 * * * \\
(3.06)\end{array}$ \\
\hline$N$ & 7902 & 7902 & 7538 & 7538 \\
\hline$R^{2}$ & 0.931 & 0.931 & 0.793 & 0.793 \\
\hline
\end{tabular}

Notes: This table presents the regression results of dividend payouts on market-to-book ratio in full sample. Market-to-book ratio, the dependent variable, is the market value divided by the book value of the firm. CD ratio denotes the cash dividend payout ratio. UP is a dummy for companies from paying below $30 \%$ of net profits to paying $30 \%$ and beyond in current year, and DOWN is a dummy for firms from paying $30 \%$ or more to less than $30 \%$. SIZE is the natural logarithm of total asset, LEVERAGE is the total liability divided by total asset, STAGE is the retained earnings divided by total asset, and AGE denotes the total operating days of the firm since established. IND is the industry dummies, and YEAR represents the year dummies. We use the Rogers sandwich cluster-robust standard errors in the full sample calculation of t-value. T-statistics are in parentheses.

$* * *, * *$ and $*$ denote Significance at 1, 5 and $10 \%$ levels, respectively.

Table 5 shows details for the full-sample regression of the market-to-book ratio. For the short-term and middle-term analyses, the R-squared values are $93 \%$ and $79 \%$, respectively. In the short-term analysis, the coefficients of 
$C D$ Ratio are negatively significant. Both the UP and DOWN values are insignificantly positive. Again, the evidence suggests that investors on the SSE do not give more credit to dividend payers, and becoming a quality payer does not ensure a superior valuation. As shown in Columns (3) and (4), all of the cash-dividend variables of the middle-term analysis are positive; however, only the UP dummy is marginally significant in determining firm value.

\section{Concluding Remarks}

This study examines the effects of government-guided cash dividend payouts on firm value by analyzing a sample of A-share firms listed on the SSE, China. Findings based on results from a 2013 subsample analysis suggest that firms following the "Guidelines" are rewarded with a Tobin's Q higher than those of others in the short term. However, the effect disappears in the middle term. Furthermore, paying cash dividends can harm corporate value in the short term according to the full-sample analysis. Small, young, and low-leverage firms enjoy high Tobin's Qs in China.

The results provide practical policy implications for equity market participants and suggest that equity investors on the SSE value stocks from a different perspective than the authorities in China do. The China Securities Regulatory Commission, the body overseeing the securities markets in China, has devoted itself to establishing a reliable, efficiently functioning market and therefore directed the SSE to introduce the guideline regarding cash dividends in 2013. The results indicate that the authorities in China should focus more attention on other functions of the markets and allow firms to decide their payout levels.

\section{Acknowledgements}

We thank Marcell Dülk and conference participants at SSEM Euro Conference 2014 for helpful comments. All errors remain our own responsibility. This work was supported by the Fundamental Research Funds for the Central Universities under Grant (HIT.HSSS.201502).

\section{Appendix}

Table A1. Dividend Payers, Non-Payers, and Quality Payers.

\begin{tabular}{|c|c|c|c|c|c|c|c|}
\hline IND & Year & Payer & Nonpayer & $\mathbf{Q P}$ & Firms & Payer\% & QP\% \\
\hline \multirow{9}{*}{$\begin{array}{l}\text { Agriculture, forestry, animal husbandry } \\
\text { and fishery }\end{array}$} & 2004 & 1 & 9 & 1 & 10 & $10.00 \%$ & $10.00 \%$ \\
\hline & 2005 & 6 & 6 & 4 & 12 & $50.00 \%$ & $33.33 \%$ \\
\hline & 2006 & 7 & 9 & 6 & 16 & $43.75 \%$ & $37.50 \%$ \\
\hline & 2007 & 7 & 9 & 5 & 16 & $43.75 \%$ & $31.25 \%$ \\
\hline & 2008 & 7 & 9 & 6 & 16 & $43.75 \%$ & $37.50 \%$ \\
\hline & 2009 & 6 & 10 & 6 & 16 & $37.50 \%$ & $37.50 \%$ \\
\hline & 2010 & 7 & 9 & 7 & 16 & $43.75 \%$ & $43.75 \%$ \\
\hline & 2012 & 7 & 10 & 4 & 17 & $41.18 \%$ & $23.53 \%$ \\
\hline & 2013 & 10 & 7 & 7 & 17 & $58.82 \%$ & $41.18 \%$ \\
\hline \multirow{8}{*}{ Mining } & 2004 & 8 & 8 & 6 & 16 & $50.00 \%$ & $37.50 \%$ \\
\hline & 2005 & 11 & 9 & 6 & 20 & $55.00 \%$ & $30.00 \%$ \\
\hline & 2006 & 13 & 11 & 10 & 24 & $54.17 \%$ & $41.67 \%$ \\
\hline & 2007 & 13 & 11 & 9 & 24 & $54.17 \%$ & $37.50 \%$ \\
\hline & 2008 & 15 & 12 & 7 & 27 & $55.56 \%$ & $25.93 \%$ \\
\hline & 2011 & 24 & 11 & 9 & 35 & $68.57 \%$ & $25.71 \%$ \\
\hline & 2012 & 27 & 9 & 10 & 36 & $75.00 \%$ & $27.78 \%$ \\
\hline & 2013 & 29 & 7 & 17 & 36 & $80.56 \%$ & $47.22 \%$ \\
\hline \multirow{10}{*}{ Manufacturing } & 2004 & 182 & 165 & 124 & 347 & $52.45 \%$ & $35.73 \%$ \\
\hline & 2005 & 232 & 158 & 154 & 390 & $59.49 \%$ & $39.49 \%$ \\
\hline & 2006 & 220 & 201 & 144 & 421 & $52.26 \%$ & $34.20 \%$ \\
\hline & 2007 & 213 & 208 & 124 & 421 & $50.59 \%$ & $29.45 \%$ \\
\hline & 2008 & 220 & 204 & 96 & 424 & $51.89 \%$ & $22.64 \%$ \\
\hline & 2009 & 202 & 223 & 89 & 425 & $47.53 \%$ & $20.94 \%$ \\
\hline & 2010 & 220 & 207 & 102 & 427 & $51.52 \%$ & $23.89 \%$ \\
\hline & 2011 & 230 & 202 & 86 & 432 & $53.24 \%$ & $19.91 \%$ \\
\hline & 2012 & 243 & 201 & 99 & 444 & $54.73 \%$ & $22.30 \%$ \\
\hline & 2013 & 299 & 168 & 177 & 467 & $64.03 \%$ & $37.90 \%$ \\
\hline \multirow{6}{*}{$\begin{array}{l}\text { Electric power, heat, gas and water } \\
\text { production and supply }\end{array}$} & 2004 & 20 & 11 & 16 & 31 & $64.52 \%$ & $51.61 \%$ \\
\hline & 2005 & 28 & 5 & 19 & 33 & $84.85 \%$ & $57.58 \%$ \\
\hline & 2008 & 30 & 11 & 20 & 41 & $73.17 \%$ & $48.78 \%$ \\
\hline & 2009 & 25 & 16 & 16 & 41 & $60.98 \%$ & $39.02 \%$ \\
\hline & 2010 & 25 & 16 & 14 & 41 & $60.98 \%$ & $34.15 \%$ \\
\hline & 2011 & 29 & 14 & 12 & 43 & $67.44 \%$ & $27.91 \%$ \\
\hline
\end{tabular}




\begin{tabular}{|c|c|c|c|c|c|c|c|}
\hline IND & Year & Payer & Nonpayer & $\mathbf{Q P}$ & Firms & Payer\% & QP\% \\
\hline \multirow{12}{*}{ Construction } & 2012 & 29 & 15 & 14 & 44 & $65.91 \%$ & $31.82 \%$ \\
\hline & 2013 & 38 & 7 & 24 & 45 & $84.44 \%$ & $53.33 \%$ \\
\hline & 2004 & 6 & 5 & 4 & 11 & $54.55 \%$ & $36.36 \%$ \\
\hline & 2005 & 8 & 7 & 5 & 15 & $53.33 \%$ & $33.33 \%$ \\
\hline & 2006 & 10 & 9 & 6 & 19 & $52.63 \%$ & $31.58 \%$ \\
\hline & 2007 & 12 & 7 & 7 & 19 & $63.16 \%$ & $36.84 \%$ \\
\hline & 2008 & 9 & 10 & 4 & 19 & $47.37 \%$ & $21.05 \%$ \\
\hline & 2009 & 13 & 8 & 8 & 21 & $61.90 \%$ & $38.10 \%$ \\
\hline & 2010 & 14 & 7 & 2 & 21 & $66.67 \%$ & $9.52 \%$ \\
\hline & 2011 & 17 & 6 & 1 & 23 & $73.91 \%$ & $4.35 \%$ \\
\hline & 2012 & 14 & 9 & 1 & 23 & $60.87 \%$ & $4.35 \%$ \\
\hline & 2013 & 22 & 5 & 6 & 27 & $81.48 \%$ & $22.22 \%$ \\
\hline \multirow{10}{*}{ Wholesale and retail } & 2004 & 31 & 35 & 22 & 66 & $46.97 \%$ & $33.33 \%$ \\
\hline & 2005 & 36 & 32 & 28 & 68 & $52.94 \%$ & $41.18 \%$ \\
\hline & 2006 & 31 & 39 & 24 & 70 & $44.29 \%$ & $34.29 \%$ \\
\hline & 2007 & 35 & 35 & 24 & 70 & $50.00 \%$ & $34.29 \%$ \\
\hline & 2008 & 33 & 37 & 17 & 70 & $47.14 \%$ & $24.29 \%$ \\
\hline & 2009 & 38 & 32 & 22 & 70 & $54.29 \%$ & $31.43 \%$ \\
\hline & 2010 & 37 & 33 & 16 & 70 & $52.86 \%$ & $22.86 \%$ \\
\hline & 2011 & 38 & 32 & 10 & 70 & $54.29 \%$ & $14.29 \%$ \\
\hline & 2012 & 48 & 25 & 17 & 73 & $65.75 \%$ & $23.29 \%$ \\
\hline & 2013 & 49 & 26 & 27 & 75 & $65.33 \%$ & $36.00 \%$ \\
\hline \multirow{10}{*}{ Transport, storage and postal service } & 2004 & 19 & 11 & 14 & 30 & $63.33 \%$ & $46.67 \%$ \\
\hline & 2005 & 28 & 7 & 17 & 35 & $80.00 \%$ & $48.57 \%$ \\
\hline & 2006 & 31 & 7 & 20 & 38 & $81.58 \%$ & $52.63 \%$ \\
\hline & 2007 & 27 & 11 & 21 & 38 & $71.05 \%$ & $55.26 \%$ \\
\hline & 2008 & 32 & 11 & 20 & 43 & $74.42 \%$ & $46.51 \%$ \\
\hline & 2009 & 35 & 11 & 17 & 46 & $76.09 \%$ & $36.96 \%$ \\
\hline & 2010 & 31 & 15 & 12 & 46 & $67.39 \%$ & $26.09 \%$ \\
\hline & 2011 & 33 & 14 & 15 & 47 & $70.21 \%$ & $31.91 \%$ \\
\hline & 2012 & 42 & 10 & 19 & 52 & $80.77 \%$ & $36.54 \%$ \\
\hline & 2013 & 41 & 11 & 25 & 52 & $78.85 \%$ & $48.08 \%$ \\
\hline \multirow{10}{*}{ Accommodation and catering } & 2004 & 2 & 0 & 2 & 2 & $100.00 \%$ & $100.00 \%$ \\
\hline & 2005 & 2 & 0 & 2 & 2 & $100.00 \%$ & $100.00 \%$ \\
\hline & 2006 & 2 & 0 & 2 & 2 & $100.00 \%$ & $100.00 \%$ \\
\hline & 2007 & 2 & 0 & 2 & 2 & $100.00 \%$ & $100.00 \%$ \\
\hline & 2008 & 3 & 0 & 3 & 3 & $100.00 \%$ & $100.00 \%$ \\
\hline & 2009 & 2 & 1 & 2 & 3 & $66.67 \%$ & $66.67 \%$ \\
\hline & 2010 & 2 & 1 & 2 & 3 & $66.67 \%$ & $66.67 \%$ \\
\hline & 2011 & 3 & 0 & 2 & 3 & $100.00 \%$ & $66.67 \%$ \\
\hline & 2012 & 2 & 1 & 2 & 3 & $66.67 \%$ & $66.67 \%$ \\
\hline & 2013 & 3 & 0 & 2 & 3 & $100.00 \%$ & $66.67 \%$ \\
\hline \multirow{10}{*}{$\begin{array}{l}\text { Information transmission, software and } \\
\text { information technology services }\end{array}$} & 2004 & 12 & 5 & 8 & 17 & $70.59 \%$ & $47.06 \%$ \\
\hline & 2005 & 13 & 8 & 9 & 21 & $61.90 \%$ & $42.86 \%$ \\
\hline & 2006 & 12 & 11 & 10 & 23 & $52.17 \%$ & $43.48 \%$ \\
\hline & 2007 & 11 & 12 & 5 & 23 & $47.83 \%$ & $21.74 \%$ \\
\hline & 2008 & 12 & 11 & 3 & 23 & $52.17 \%$ & $13.04 \%$ \\
\hline & 2009 & 14 & 9 & 5 & 23 & $60.87 \%$ & $21.74 \%$ \\
\hline & 2010 & 12 & 11 & 3 & 23 & $52.17 \%$ & $13.04 \%$ \\
\hline & 2011 & 12 & 11 & 4 & 23 & $52.17 \%$ & $17.39 \%$ \\
\hline & 2012 & 17 & 7 & 5 & 24 & $70.83 \%$ & $20.83 \%$ \\
\hline & 2013 & 17 & 7 & 11 & 24 & $70.83 \%$ & $45.83 \%$ \\
\hline \multirow{10}{*}{ Financial industry } & 2004 & 5 & 4 & 2 & 9 & $55.56 \%$ & $22.22 \%$ \\
\hline & 2005 & 6 & 5 & 2 & 11 & $54.55 \%$ & $18.18 \%$ \\
\hline & 2006 & 6 & 5 & 2 & 11 & $54.55 \%$ & $18.18 \%$ \\
\hline & 2007 & 5 & 6 & 2 & 11 & $45.45 \%$ & $18.18 \%$ \\
\hline & 2008 & 11 & 5 & 3 & 16 & $68.75 \%$ & $18.75 \%$ \\
\hline & 2009 & 18 & 5 & 9 & 23 & $78.26 \%$ & $39.13 \%$ \\
\hline & 2010 & 18 & 5 & 8 & 23 & $78.26 \%$ & $34.78 \%$ \\
\hline & 2011 & 18 & 7 & 9 & 25 & $72.00 \%$ & $36.00 \%$ \\
\hline & 2012 & 26 & 3 & 17 & 29 & $89.66 \%$ & $58.62 \%$ \\
\hline & 2013 & 31 & 1 & 23 & 32 & $96.88 \%$ & $71.88 \%$ \\
\hline \multirow{5}{*}{ Real estate } & 2004 & 22 & 35 & 14 & 57 & $38.60 \%$ & $24.56 \%$ \\
\hline & 2005 & 27 & 32 & 17 & 59 & $45.76 \%$ & $28.81 \%$ \\
\hline & 2006 & 25 & 36 & 16 & 61 & $40.98 \%$ & $26.23 \%$ \\
\hline & 2007 & 26 & 35 & 18 & 61 & $42.62 \%$ & $29.51 \%$ \\
\hline & 2008 & 25 & 38 & 10 & 63 & $39.68 \%$ & $15.87 \%$ \\
\hline
\end{tabular}




\begin{tabular}{|c|c|c|c|c|c|c|c|}
\hline IND & Year & Payer & Nonpayer & $\mathbf{Q P}$ & Firms & Payer\% & QP\% \\
\hline \multirow{15}{*}{ Leasing and commercial service } & 2009 & 31 & 32 & 9 & 63 & $49.21 \%$ & $14.29 \%$ \\
\hline & 2010 & 31 & 32 & 8 & 63 & $49.21 \%$ & $12.70 \%$ \\
\hline & 2011 & 33 & 30 & 8 & 63 & $52.38 \%$ & $12.70 \%$ \\
\hline & 2012 & 35 & 28 & 7 & 63 & $55.56 \%$ & $11.11 \%$ \\
\hline & 2013 & 50 & 13 & 22 & 63 & $79.37 \%$ & $34.92 \%$ \\
\hline & 2004 & 3 & 4 & 2 & 7 & $42.86 \%$ & $28.57 \%$ \\
\hline & 2005 & 3 & 4 & 3 & 7 & $42.86 \%$ & $42.86 \%$ \\
\hline & 2006 & 3 & 4 & 3 & 7 & $42.86 \%$ & $42.86 \%$ \\
\hline & 2007 & 3 & 4 & 3 & 7 & $42.86 \%$ & $42.86 \%$ \\
\hline & 2008 & 3 & 4 & 3 & 7 & $42.86 \%$ & $42.86 \%$ \\
\hline & 2009 & 3 & 4 & 1 & 7 & $42.86 \%$ & $14.29 \%$ \\
\hline & 2010 & 2 & 5 & 1 & 7 & $28.57 \%$ & $14.29 \%$ \\
\hline & 2011 & 3 & 5 & 1 & 8 & $37.50 \%$ & $12.50 \%$ \\
\hline & 2012 & 4 & 4 & 1 & 8 & $50.00 \%$ & $12.50 \%$ \\
\hline & 2013 & 5 & 3 & 2 & 8 & $62.50 \%$ & $25.00 \%$ \\
\hline \multirow{10}{*}{ Scientific research and technical service } & 2004 & 0 & 1 & 0 & 1 & $0.00 \%$ & $0.00 \%$ \\
\hline & 2005 & 0 & 1 & 0 & 1 & $0.00 \%$ & $0.00 \%$ \\
\hline & 2006 & 0 & 1 & 0 & 1 & $0.00 \%$ & $0.00 \%$ \\
\hline & 2007 & 0 & 1 & 0 & 1 & $0.00 \%$ & $0.00 \%$ \\
\hline & 2008 & 0 & 1 & 0 & 1 & $0.00 \%$ & $0.00 \%$ \\
\hline & 2009 & 0 & 1 & 0 & 1 & $0.00 \%$ & $0.00 \%$ \\
\hline & 2010 & 0 & 1 & 0 & 1 & $0.00 \%$ & $0.00 \%$ \\
\hline & 2011 & 1 & 1 & 0 & 2 & $50.00 \%$ & $0.00 \%$ \\
\hline & 2012 & 1 & 1 & 0 & 2 & $50.00 \%$ & $0.00 \%$ \\
\hline & 2013 & 1 & 1 & 0 & 2 & $50.00 \%$ & $0.00 \%$ \\
\hline \multirow{10}{*}{$\begin{array}{l}\text { Water conservancy, environment and } \\
\text { public facility management }\end{array}$} & 2004 & 3 & 1 & 3 & 4 & $75.00 \%$ & $75.00 \%$ \\
\hline & 2005 & 3 & 1 & 3 & 4 & $75.00 \%$ & $75.00 \%$ \\
\hline & 2006 & 4 & 0 & 4 & 4 & $100.00 \%$ & $100.00 \%$ \\
\hline & 2007 & 3 & 1 & 3 & 4 & $75.00 \%$ & $75.00 \%$ \\
\hline & 2008 & 2 & 2 & 1 & 4 & $50.00 \%$ & $25.00 \%$ \\
\hline & 2009 & 3 & 1 & 2 & 4 & $75.00 \%$ & $50.00 \%$ \\
\hline & 2010 & 3 & 1 & 2 & 4 & $75.00 \%$ & $50.00 \%$ \\
\hline & 2011 & 3 & 1 & 1 & 4 & $75.00 \%$ & $25.00 \%$ \\
\hline & 2012 & 3 & 1 & 1 & 4 & $75.00 \%$ & $25.00 \%$ \\
\hline & 2013 & 4 & 0 & 2 & 4 & $100.00 \%$ & $50.00 \%$ \\
\hline \multirow{10}{*}{$\begin{array}{l}\text { Resident service, repair and other } \\
\text { services }\end{array}$} & 2004 & 1 & 0 & 0 & 1 & $100.00 \%$ & $0.00 \%$ \\
\hline & 2005 & 1 & 0 & 0 & 1 & $100.00 \%$ & $0.00 \%$ \\
\hline & 2006 & 1 & 0 & 0 & 1 & $100.00 \%$ & $0.00 \%$ \\
\hline & 2007 & 1 & 0 & 0 & 1 & $100.00 \%$ & $0.00 \%$ \\
\hline & 2008 & 0 & 1 & 0 & 1 & $0.00 \%$ & $0.00 \%$ \\
\hline & 2009 & 1 & 0 & 0 & 1 & $100.00 \%$ & $0.00 \%$ \\
\hline & 2010 & 1 & 0 & 1 & 1 & $100.00 \%$ & $100.00 \%$ \\
\hline & 2011 & 1 & 0 & 0 & 1 & $100.00 \%$ & $0.00 \%$ \\
\hline & 2012 & 1 & 0 & 0 & 1 & $100.00 \%$ & $0.00 \%$ \\
\hline & 2013 & 1 & 0 & 0 & 1 & $100.00 \%$ & $0.00 \%$ \\
\hline \multirow{10}{*}{ Health and social work } & 2004 & 0 & 1 & 0 & 1 & $0.00 \%$ & $0.00 \%$ \\
\hline & 2005 & 0 & 1 & 0 & 1 & $0.00 \%$ & $0.00 \%$ \\
\hline & 2006 & 0 & 1 & 0 & 1 & $0.00 \%$ & $0.00 \%$ \\
\hline & 2007 & 0 & 1 & 0 & 1 & $0.00 \%$ & $0.00 \%$ \\
\hline & 2008 & 0 & 1 & 0 & 1 & $0.00 \%$ & $0.00 \%$ \\
\hline & 2009 & 0 & 1 & 0 & 1 & $0.00 \%$ & $0.00 \%$ \\
\hline & 2010 & 0 & 1 & 0 & 1 & $0.00 \%$ & $0.00 \%$ \\
\hline & 2011 & 0 & 1 & 0 & 1 & $0.00 \%$ & $0.00 \%$ \\
\hline & 2012 & 0 & 1 & 0 & 1 & $0.00 \%$ & $0.00 \%$ \\
\hline & 2013 & 0 & 1 & 0 & 1 & $0.00 \%$ & $0.00 \%$ \\
\hline \multirow{10}{*}{ Culture, sports and entertainment } & 2004 & 3 & 4 & 2 & 7 & $42.86 \%$ & $28.57 \%$ \\
\hline & 2005 & 2 & 5 & 1 & 7 & $28.57 \%$ & $14.29 \%$ \\
\hline & 2006 & 3 & 4 & 1 & 7 & $42.86 \%$ & $14.29 \%$ \\
\hline & 2007 & 2 & 5 & 1 & 7 & $28.57 \%$ & $14.29 \%$ \\
\hline & 2008 & 2 & 5 & 1 & 7 & $28.57 \%$ & $14.29 \%$ \\
\hline & 2009 & 4 & 4 & 2 & 8 & $50.00 \%$ & $25.00 \%$ \\
\hline & 2010 & 4 & 4 & 0 & 8 & $50.00 \%$ & $0.00 \%$ \\
\hline & 2011 & 4 & 5 & 1 & 9 & $44.44 \%$ & $11.11 \%$ \\
\hline & 2012 & 7 & 3 & 3 & 10 & $70.00 \%$ & $30.00 \%$ \\
\hline & 2013 & 10 & 2 & 5 & 12 & $83.33 \%$ & $41.67 \%$ \\
\hline \multirow{2}{*}{ Diversified } & 2004 & 9 & 16 & 5 & 25 & $36.00 \%$ & $20.00 \%$ \\
\hline & 2005 & 9 & 17 & 8 & 26 & $34.62 \%$ & $30.77 \%$ \\
\hline
\end{tabular}




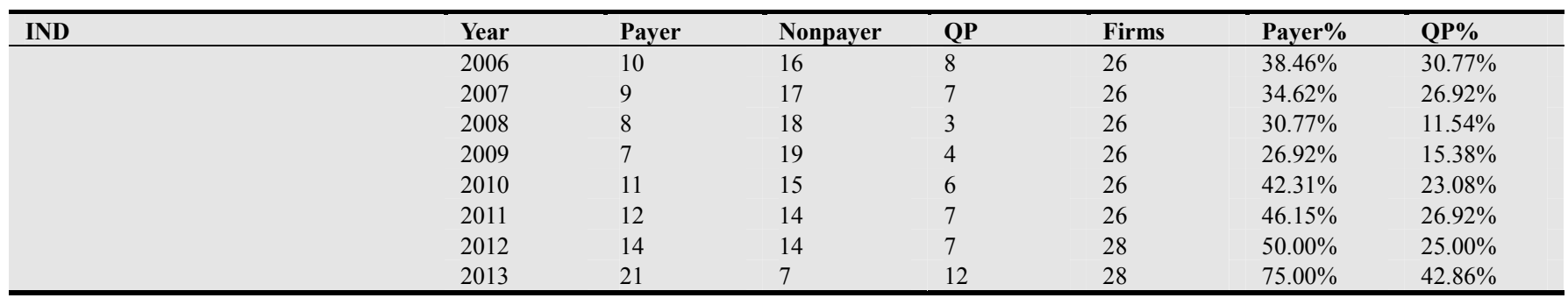

\section{References}

[1] Fama, E. and French, K. (2001) Disappearing dividends: changing firm characteristics or lower propensity to pay? Journal of Financial Economics, 60, 3-43.

[2] DeAngelo, H., DeAngelo, L. and Skinner, D. (2004) Are dividends disappearing? Dividend concentration and the consolidation of earnings, Journal of Financial Economics, 72, 425-456.

[3] Baker, M. and Wurgler, J. (2004a) A catering theory of dividends, Journal of Finance, 59, 1125-1165.

[4] Baker, M. and Wurgler, J. (2004b) Appearing and disappearing dividends: the link to catering Incentives, Journal of Financial Economics, 73, 271-288.

[5] Kuo, J. M., Philip, D. and Zhang, Q. (2013) What drives the disappearing dividends phenomenon? Journal of Banking \& Finance, 37, 3499-3514.
[6] DeAngelo, H., DeAngelo, L. and Stulz, R. (2006) Dividend policy and the earned/contributed capital mix: a test of the lifecycle theory, Journal of Financial Economics, 81, 227254.

[7] Wang, F. Q. (2013) Cash dividends policy and enterprise life cycle: empirical research based on listed companies of China, The Theory and Practice of Finance and Economics, 34, 74-77.

[8] Liu, Y. (2012) Empirical Study on the distribution of cash dividends of China listed companies: perspectives of life cycle theory, The Chinese Certified Public Accountant, 6, 97-101.

[9] Liu, J. and Guo, X. (2009) Analysis of listing companies' cash distribution policy. Friends of Accounting, 2009, 85-86.

[10] Wooldridge, J. M. (2002) Econometric Analysis of Cross Section and Panel Data. Cambridge, MA: MIT Press. 